Огляди літератури, оригінальні дослідження, погляд на проблему, випадок з практики, короткі повідомлення УДК 612.12-008.331.1:616-056.52-054-071.3

DOI 10.11603/1811-2471.2020.v.i1.11080

\title{
МОРФОМЕТРИЧНІ ТА АНТРОПОМЕТРИЧНІ ОБСТЕЖЕННЯ ПРИ ВЕДЕННІ ПАЦІЄНТІВ 3 АРТЕРІАЛЬНОЮ ГІПЕРТЕНЗІЄЮ ТА ОЖИРІННЯМ
}

\author{
๑Л. Ф. Матюха, О. Ю. Гончарук \\ Начіональна медична академія післядипломної освіти імені П. Л. Шупика
}

РЕЗЮМЕ. У статті висвітлено результати антропометричного та морфометричного огляду методом біоелектричного імпеданс-аналізу пацієнтів з артеріальною гіпертензією та ожирінням / надмірною вагою.

Мета - дослідити та проаналізувати антропометричні та морфометричні показники у пацієнтів з артеріальною гіпертанзією і ожирінням/зайвою вагою та порівняти показники морфометрії з антропометричними та біохімічними показниками у пацієнтів досліджуваних груп.

Матеріал і методи. Обстежено 64 пацієнти з артеріальною гіпертензією та ожирінням і 21 здорова особа.

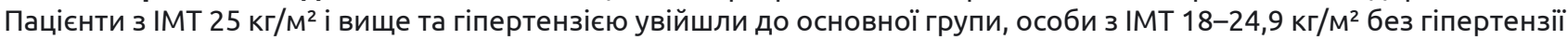
увійшли до контрольної групи. Всі пацієнти пройшли клінічне, антропометричне, морфометричне та лабораторне обстеження, яке включало в себе вимірювання АТ, визначення зросту, маси тіла, об'єму талії, шиї, кистей та стегон, визначення рівня глюкози натще, загального холестерину, лПВщ, ЛПнЩ, ЛПДНЩ, визначення коефіцієнта атерогенності та відсоткової частки жиру в організмі, виміряного методом біоімпедансметрії (БІМ). БІМ проводили аналізатором композиції тіла OMRON Body Composition Monitor BF212, (Japan), 2012 р. Статистичну обробку даних проводили за допомогою SPSS Statistics ver. 23.0.0.

Результати. Виявлені кореляційні зв'язки між антропометричними, морфометричними та лабораторними показниками, зокрема, \% ЖМТ, ІМТ і САТ та ДАТ, а також ЛПВЩ, тригліцеридами в основній групі незалежно від віку і кореляції між ІМТ та віком у групі здорових осіб.

Висновки. Відсоток ЖМ позитивно корелює з вагою тіла $(r=0,68, p=0,001)$, з IMT $(r=0,78)$ та окружністю талії $(r=0,73, p=0,001)$, стегон $(r=0,82, p=0,001)$, САТ $(r=0,45)$ та ДАТ $(r=0,48)(p<0,05)$. У групі здорових осіб виявлено сильну пряму кореляцію ІМТ з віком $\mathrm{r}=0,96, \mathrm{p}=0,03$, отже, можемо припустити, що антропометричні, морфометричні показники мають більшу вагу, ніж віковий фактор, у осіб, які мають ожиріння на фоні АГ, а у групі без АГ та ожиріння основним фактором ризику $\epsilon$ вік. Включення морфометричних вимірювань у повсякденну клінічну практику $\epsilon$ безпечним, неінвазивним, точним і достовірним методом діагностики ожиріння/зайвої ваги та визначення ризику.

КлючовІ СлОВА: ожиріння; артеріальна гіпертензія; біоімпедансметрія.

Вступ. Упродовж останніх десятиліть поширеність ожиріння в популяціях стрімко зростає. В одному з недавніх масштабних досліджень продемонстровано, що населення Землі з 1975 року кожні десять років ставало на 1,5 кг важчим [1], і ця тенденція, що продовжує розвиватися, загрожує досягти рівня епідемії у світі. В Україні на ожиріння страждає 22,1 \% населення. Для порівняння, у Великобританії цей показник становить 28,4 д для жінок та 26,2 \% для чоловіків, і $\epsilon$ найгіршим у Європі. Загалом показник ожиріння у країнах Західної Європи коливається від 20 до 24 \%. I хоча поширеність ожиріння більшою мірою асоціюється із достатком та економічним благополуччям, у зоні ризику також знаходяться країни з низьким рівнем доходу та економікою, що розвивається [2].

За прогнозами ВООЗ, у 2025 році в Україні рівень ожиріння населення досягне 25,9 \% [3].

Слід зауважити, що більше половини хворих на АГ мають супутн $є$ ожиріння різного ступеня вираженості, а основною причиною смертності як в Україні, так і в світі, досі $\epsilon$ серцево-судинні захворювання. При цьому численними дослідженнями доведено, що ожиріння у хворих на АГ сприяє скороченню тривалості, зниженню якості життя, збільшенню частоти серцево-судинних ускладнень та інвалідизації пацієнтів $[4,5]$. Прогресуюче зростання ожиріння в структурі АГ $\epsilon$ негативним чинником її клінічних проявів $[6,7]$, тому важливо вчасно діагностувати і профілактувати обидва ці захворювання для недопущення розвитку ускладнень та покращення якості життя цієї категорії пацієнтів.

Класичними антропометричними методами оцінки ступеня ожиріння наразі можна вважати вимірювання маси тіла, обводу талії, індексу талія/ стегно (для жінок у нормі менше 0,85 і чоловіків менше 0,9$)$ та визначення індексу маси тіла (IMT).

У науковій роботі, в практичній діяльності лікарів та у фітнес-сфері сьогодні набувають популярності інші методи оцінки нутрітивного статусу, зокрема, все ширшої популярності набуває метод імпедансметрії. Вперше неінвазивний біоелектричний імпеданс-аналіз був застосований Хоффером в 1969 році [8]. Його класична двокомпонентна (2C) біоелектрична імпедансметрія (БІМ) дає можливість оцінити 2 показники - жирову (ЖМ) і безжирову масу (БЖМ) $[9,10]$.

Залежно від технічних можливостей і апарату вимірювання можна оцінити також відсоток за- 
Огляди літератури, оригінальні дослідження, погляд на проблему, випадок з практики, короткі повідомлення гальної води в організмі, кісткової, скелетном'язової тканини та внутрішніх органів, а також розглянути організм на 5 рівнях - функціональному, клітинному, молекулярному та елементарному рівнях, за більш ніж 30 компонентами $[11,12]$.

Незважаючи на розмаїття інших методів, на сьогодні найпоширенішим методом оцінки нутрітивного статусу і ризику захворювання $\epsilon$ IMT [13].

У багатьох дослідженнях доведена позитивна кореляція IMT і відсотка жирової маси (\% ЖМ), але, згідно з деякими дослідженнями, існує тенденція, що навіть у людей із нормальним IMT відсоток жирової до безжирової маси тіла може бути збільшеним і варіювати від 5 до 40 \% або навпаки, у осіб з IMT близько 30 жирова маса тіла може бути нормальною [14]. Тому для точнішої оцінки ожиріння може бути використаний метод біоімпедансметрії або його поєднання з антропометрією та визначенням IMT.

Нормальним співвідношенням жирової та безжирової тканин вважають від 20/80 \% у чоловіків і до 25/75 \% у жінок [15].

Ці показники можуть варіювати, тому важливо визначати їх у даної категорії пацієнтів для загальної оцінки статусу та ризику і, за можливості, в динаміці.

3 огляду на те, що у ряді досліджень продемонстрованостатистичнозначущийкореляційний зв'язок між визначенням ЖМ за допомогою КТ, рентген- та УзД-сканування та визченням відсотка ЖМ методом біоелектричного імпедансу біоімпедансне зважування $\epsilon$ не тільки безпечним i неінвазивним, а й достовірним з погляду сучасних наукових досліджень $[16,17]$. Тому його доцільно застосовувати у практичній діяльності сімейного лікаря при веденні пацієнтів з АГ та ожирінням як маркер оцінки кардіометаболічного ризику та динаміки лікування.

Мета - дослідити та проаналізувати антропометричні й морфометричні показники у пацієнтів з АГ і ожирінням/надмірною вагою та порівняти показники морфометрії з антропометричними та біохімічними показниками у пацієнтів досліджуваної вибірки.

Матеріал і методи дослідження. Обстежено 64 пацієнти з АГ та ожирінням/зайвою вагою та 21 здорова особа у віці від 25 до 63 років (середній вік $(40,25 \pm 17,53)$ років), які склали досліджувану сукупність. Пацієнти з ІМТ 25 кг/м² і вище та АГ сформували основну групу з підвищеною масою тіла та ожирінням (20 чоловіків і 44 жінки), особи з IMT 18-24,9 кг/м² без гіпертензії увійшли до контрольної групи (7 чоловіків і 14 жінок).

Критеріями включення до основної групи були вік від 25 до 65 років та діагноз артеріальної гіпертензії І-ІІ ступенів, АТ вище 140/80 мм рт. ст.

або нижче за умови постійного прийому антигіпертензивних препаратів, IMT вище $24,9 \mathrm{kr} / \mathrm{M}^{2}$, обвід талії 80 см і більше у жінок і 94 см і більше у чоловіків. Усі хворі пройшли детальне клінічне, антропометричне, морфометричне та лабораторне обстеження, яке включало в себе вимірювання АТ, визначення зросту, маси тіла, обводу талії, шиї, кистей та стегон, а також визначення рівня глюкози натще, загального холестерину, лПВЩ, лПнЩ, лПднЩ, коефіцієнта атерогенності та відсоткової частки жиру в організмі, виміряної методом БІМ. БІМ проводили аналізатором композиції тіла OMRON Body Composition Monitor BF212, (Japan), 2012 p.

У систему платформи вагів вмонтовані два електроди, від однієї до іншої ступні через тіло проходить безпечний для людини струм 50 кГц. Вимірювання проводили стоячи босоніж, попередньо обробивши поверхню 96 \% розчином етилового спирту, при цьому попередньо вводились у програму параметри зросту, статі й віку. Точність вимірювання відстоткового вмісту жиру становила до 0,1 \% [18]. Вбудоване програмне забезпечення вимірювало відсоток жирової тканини, автоматично розраховувало IMT та вагу. Для характеристики маси тіла використовували індекс маси тіла (IMT), який також визначали за формулою: IMT $\left(\mathrm{Kr} / \mathrm{M}^{2}\right)=$ маса тіла (кг)/зріст (м)². Масу тіла вва-

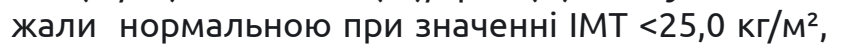

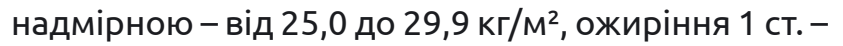
від 30,0 до $34,9 \mathrm{kr} / \mathrm{M}^{2}$, ожиріння 2 ст. - від 35,0 до $39,9 \mathrm{kr} / \mathrm{M}^{2}$, ожиріння $3 \mathrm{cт.}>40,0 \mathrm{kr} / \mathrm{M}^{2}$. Тип розподілу жирової тканини визначали згідно з показником обводу талії (ОТ). Ознакою абдомінального типу ожиріння вважали значення ОТ >94 см у чоловіків, ОТ >80 см у жінок [19]. Обводи талії і стегон вимірювали за допомогою стандартизованої медичної сантиметрової стрічки для визначення ризику метаболічного синдрому за ВОО3, а зросту - за допомогою РП-2000 медичного підлогового зростоміра. Критеріями не включення у дослідження були АГ III стадії, стабільна та нестабільна стенокардія, перенесений інфаркт міокарда, гостре порушення мозкового кровообігу в анамнезі, фракція викиду нижче 50 \%, системні інфекції, вагітність, інсулінозалежний цукровий діабет, ниркова недостатність, декомпенсовані захворювання печінки (підвищення рівня трансаміназ більше ніж утричі, загального білірубіну - більше ніж удвічі), гіпер- або гіпофункції щитоподібної залози, онкологічні процеси.

Статистичну обробку даних проводили за допомогою SPSS Statistics ver. 23.0.0. Перевірку статистичної бази щодо розподілу пацієнтів проводили за допомогою критеріїв Колмогорова, Смірнова та W-критерію Шапіро-Уїлка (якщо значення 
Огляди літератури, оригінальні дослідження, погляд на проблему, випадок з практики, короткі повідомлення було більше 1 - розподіл вважали не нормальним).

Вірогідність різниці між групами порівняння визначали за допомогою U критерію МанаУїтні.

Кореляційний зв'язок між показниками оцінювали за допомогою коефіцієнта кореляції Пірсона. При г<0,3 кореляцію оцінювали як слабку, від 0,3 до 0,7 - як середньої сили, >0,7 - як сильну кореляцію, і більше 0,9 - як дуже сильну кореляцію. Для усіх розрахованих значень значущою вважали загальноприйняту різницю похибки 3 $p<0,05$.

Результати й обговорення. Дослідження проводили на клінічних базах кафедри сімейної

медицини та амбулаторно-поліклінічної допомоги НМАПО імені П. Л. Шупика.

Ми провели дослідження клінічних, антропометричних, морфометричних та лабораторних характеристик у 64 пацієнтів віком від 25 до 63 років з АГ та ожирінням/або зайвою вагою та 21 здорової особи. Верифікацію діагнозу ГХ проводили згідно з рекомендаціями Української асоціації кардіологів [20]. Діагноз ожиріння встановлювали відповідно до класифікації ВООЗ [21].

Порівняльний аналіз середніх значень отриманих антропометричних показників, рівня систолічного АТ (САТ), діастолічного АТ (ДАТ), ваги, віку, індексу маси тіла, \% ЖМ, обводу талії, стегон, шиї, кистей подано в таблиці 1.

Таблиця 1. Характеристика антропометричних та морфометричних даних досліджуваної сукупності

\begin{tabular}{|l|c|c|c|}
\hline \multicolumn{1}{|c|}{ Показники } & $\begin{array}{c}\text { Група хворих на АГ } \\
(\mathrm{n=64)}\end{array}$ & $\begin{array}{c}\text { Контрольна група } \\
(\mathrm{n}=21)\end{array}$ & $\mathrm{P}$ \\
\hline Чоловіки, $\mathrm{n}(\%)$ & $22(34,38)$ & $7(33,33)$ & $14(66,67)$ \\
Жінки, $\mathrm{n}(\%)$ & $42(65,63)$ & $120,47 \pm 0,47$ & $\mathrm{P}=0,035$ \\
\hline САТ, мм рт. ст & $151,88 \pm 13,52^{*}$ & $80,47 \pm 0,47$ & $\mathrm{P}=0,035$ \\
\hline ДАТ, мм рт. ст. & $101,47 \pm 5,72^{*}$ & $58,35 \pm 16,02$ & $\mathrm{P}=0,035$ \\
\hline Вага & $88,62 \pm 21,01^{*}$ & $21,14 \pm 2,83$ & $\mathrm{P}=0,035$ \\
\hline ІМТ & $32,13 \pm 6,97^{*}$ & $29,3 \pm 1,73$ & $\mathrm{P}=0,035$ \\
\hline$\%$ ЖМ & $40,57 \pm 8,52^{*}$ & $69,75 \pm 6,84$ & $\mathrm{P}=0,035$ \\
\hline Обвід талії & $109,33 \pm 18,82^{*}$ & $93,5 \pm 0,81$ & $\mathrm{P}=0,035$ \\
\hline Обвід стегон & $111,72 \pm 8,7^{*}$ & $30,5 \pm 2,64$ & $\mathrm{P}=0,04$ \\
\hline Обвід шиї & $39,5 \pm 4,04^{*}$ & $14,87 \pm 0,85$ & $\mathrm{P}=0,04$ \\
\hline Обвід кистей & $17,88 \pm 1,84^{*}$ & & \\
\hline
\end{tabular}

Примітка. \% ЖМ - відсоток жирової маси; ІМТ - індекс маси тіла; САТ - систолічний артеріальний тиск; ДАТ - діастолічний артеріальний тиск.

Вагу визначали за допомогою OMRON Body Composition Monitor BF212, Japan, 2012 p.

При аналізі середніх значень: ваги, IMT, ОT, АТ, \% ЖМ, обводів талії, стегон, шиї, кистей, виявили, що середні значення цих показників у основній групі були достовірно вищі $(p<0,05)$, ніж у контрольній групі здорових осіб, незалежно від ступеня супутнього ожиріння. При аналізі абсолютних показників рівня ЖМ з'ясовано, що підвищення рівня ЖМ виявлено у всіх хворих на АГ та ожиріння. Під час дослідження показників основної групи кластерно ми визначили основну тенденцію показників жирової маси, які розподілились наступним чином - 40 \% мали \% жМ 40-45, 15 \% пацієнтів основної групи мали \% ЖМ 45-50 та 50-55, по $10 \%$ осіб мали \% ЖМ 20-25 та від 30 до 35 і по 5 \% пацієнтів із АГ та ожирінням мали жирову масу 25-30 та 35-40\% (рис. 1).

Результати середніх величин та стандартного відхилення лабораторних показників досліджуваних груп представлені у таблиці 2.

Як видно з даних, наведених у таблиці 2, середній рівень глюкози в основній групі склав $(4,6 \pm$

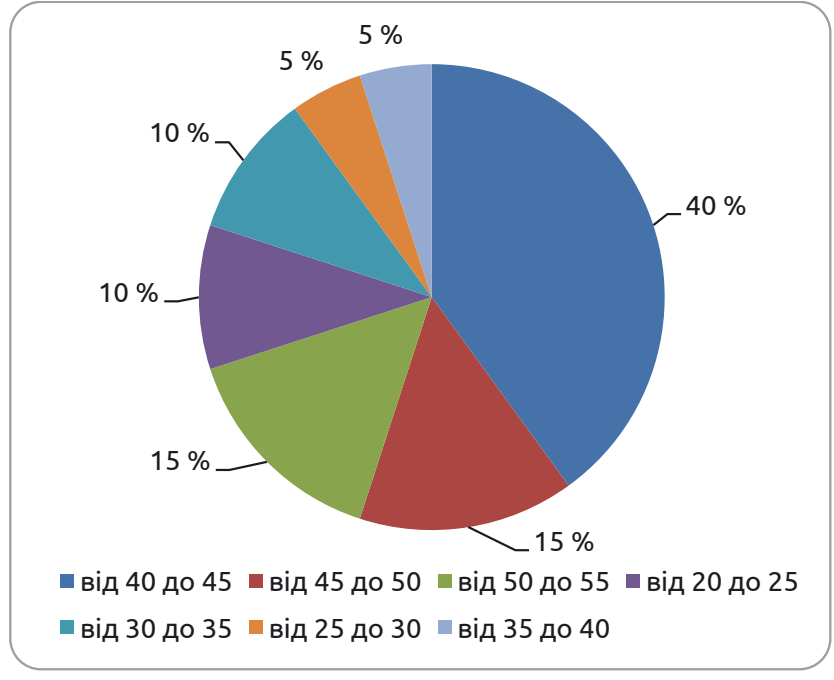

Рис. 1. Розподіл пацієнтів з артеріальною гіпертензією залежно від \% ЖМ.

$0,7)$ ммоль/л, у контрольній $(4,0 \pm 0,11)$ ммоль/л, рівень загального холестерину $(5,6 \pm 1,01)$ ммоль/л і 
Огляди літератури, оригінальні дослідження, погляд на проблему, випадок з практики, короткі повідомлення Таблиця 2. Лабораторні показники пацієнтів досліджуваних груп

\begin{tabular}{|l|c|c|c|}
\hline \multicolumn{1}{|c|}{ Показники } & Основна група & Група контролю & $\mathrm{p}$ \\
\hline Глюкоза, ммоль/л & $4,6 \pm 0,7$ & $4,0 \pm 0,11$ & $\mathrm{p}<0,05$ \\
\hline Холестерин загальний, ммоль/л & $5,6 \pm 1,01$ & $4,67 \pm 0,84$ & $\mathrm{p}<0,05$ \\
\hline Тригліцериди, ммоль/л & $1,41 \pm 0,8$ & $0,78 \pm 0,5$ & $\mathrm{p}<0,05$ \\
\hline ЛПВЩ, ммоль/л & $1,45 \pm 0,3$ & $1,73 \pm 0,1$ & $\mathrm{p}<0,05$ \\
\hline ЛПнЩ, ммоль/л & $3,5 \pm 0,95$ & $3,6 \pm 0,32$ & $\mathrm{p}<0,05$ \\
\hline ЛПднЩ, ммоль/л & $0,64 \pm 0,36$ & $0,34 \pm 0,03$ & $\mathrm{p}<0,05$ \\
\hline Коефіцієнт атерогенності & $3,97 \pm 0,89$ & $2,49 \pm 0,2$ & $\mathrm{p}<0,05$ \\
\hline
\end{tabular}

$(4,67 \pm 0,84)$ ммоль/л відповідно, тригліцеридів $(1,41 \pm 0,8)$ ммоль/л і $(0,78 \pm 0,5)$ ммоль/л - відповідно. Середні показники лпвЩ в основній групі склали $(1,45 \pm 0,3)$ ммоль/л, у контрольній - $(1,73 \pm$ $0,1)$ ммоль/л, лПнЩ - $(3,5 \pm 0,95)$ ммоль/л і $(3,6 \pm$ $0,32)$ ммоль/л, а лПДнщ - $(0,64 \pm 0,36)$ ммоль/л та $(0,34 \pm 0,03)$ ммоль/л відповідно. Середні показники коефіцієнта атерогенності дорівнювали $3,97 \pm 0,89$

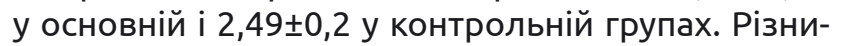
ця між досліджуваними групами достовірна на рівні похибки $р<0,05$.

Щоби дослідити взаємозв'язки між антропометричними, біоімпедансними та лабораторними показниками, що вивчалися, ми провели кореляційний аналіз. Встановлено, що відсоток жирової маси в основній групі, виміряний методом біоімпедансметрії, позитивно корелював з усіма антропометричними показниками на рівні значимості не менше ніж $p<0,05$, окрім віку. Відсоток жирової маси позитивно корелював з вагою тіла - $r=0,68$, $(p<0,001)$. Виявлена пряма позитивна кореляція між ІМТ та відсотком ЖМ на рівні $r=0,79(p<0,001)$. Виявлено також взаємозв'язок значної сили між відсотком жирової маси та обводом талії - $r=0,73$ $(p<0,001)$ і стегон - $r=0,82(p<0,001)$, що, очевидно, $\epsilon$ наслідком та ознакою переважного накопичення жирової тканини у цих ділянках. 3 обводом шиї виявлений прямий кореляційний зв'язок середньої сили - $r=0,5$ ( $p=0,017)$. 3 обводом кистей жирова маса має середню силу кореляції - $r=0,45$ ( $p=0,032)$. У контрольній групі визначено, що значний рівень кореляційного зв'язку спостерігався між IMT та віком пацієнтів - $r=0,96(p=0,03)$. Інших статистично значущих кореляцій у групі здорових осіб не виявлено. В основній групі також мала місце тенденція залежності рівнів АТ від \% ЖМ, зокрема рівень САТ корелював на рівні $r=0,45$ та рівень діастолічного AT $-r=0,48(p<0,05)$.

Результати визначення кореляційних зв'язків відображені в таблицях 3 і 4.

Таблиця 3. Кореляційні звязки між \% ЖМ, ІМТ, обводом талії, стегон, шиї, кистей, показниками систолічного та діастолічного артеріального тиску

\begin{tabular}{|l|c|c|c|c|c|c|c|c|c|}
\hline & $\%$ Жм & ІМТ & $\begin{array}{c}\text { Обвід } \\
\text { талії }\end{array}$ & $\begin{array}{c}\text { Обвід } \\
\text { стегон }\end{array}$ & $\begin{array}{c}\text { Обвід } \\
\text { шиї }\end{array}$ & $\begin{array}{c}\text { Обвід } \\
\text { кистей }\end{array}$ & Вік & САТ & ДАТ \\
\hline \% ЖМ & 1 & & & & & & & & \\
\hline ІМТ & 0,78 & 1 & & & & & & & \\
\hline Обвід талії & 0,74 & 0,94 & 1 & & & & & & \\
\hline Обвід стегон & 0,82 & 0,86 & 0,87 & 1 & & & & & \\
\hline Обвід шиї & 0,50 & 0,84 & 0,89 & 0,73 & 1 & & & & \\
\hline Обвід кистей & 0,45 & 0,75 & 0,77 & 0,74 & 0,83 & 1 & & & \\
\hline Вік & 0,17 & 0,17 & 0,33 & 0,24 & 0,28 & 0,32 & 1 & & \\
\hline САТ & 0,45 & 0,51 & 0,61 & 0,68 & 0,56 & 0,53 & 0,37 & 1 & \\
\hline ДАТ & 0,48 & 0,60 & 0,64 & 0,74 & 0,57 & 0,61 & 0,27 & 0,88 & 1 \\
\hline
\end{tabular}

Примітка. В таблиці представлені числові значення R - коефіцієнта кореляції Пірсона. Рівень похибки р<0,05.

При аналізі наявності кореляційних зв'язків між результатами лабораторних обстежень та морфоантропометрією виявлено зворотний взаємозв'язок між рівнем ЛПВЩ та IMT ( $r=-0,54$, $p=0,0008)$, ЛПВЩ і САТ $(r=-0,43, p=0,04) .3$ ЖМ та ЛПВЩ виявлено зв'язок, але він не мав статистичної значимості $(r=-0,36 \mathrm{p}=0,98)$. Виявлена також кореляція між рівнем систолічного ( $r=0,54$, $\mathrm{p}=0,0087)$ і діастолічного АТ $(r=0,51 \mathrm{p}=0,01)$ та рівнем тригліцеридів. Інші лабораторні дослідження не показали статистично значущої достовірної кореляції між собою (табл. 4).

Узагальнюючи отримані нами результати можна говорити про підтвердження існуючих даних щодо впливу зайвої ваги та ожиріння загалом та відсотка жирової маси тіла, виміряного методом 
Огляди літератури, оригінальні дослідження, погляд на проблему, випадок з практики, короткі повідомлення Таблиця 4. Кореляційні зв'язки між ІМТ, \% ЖМ, САТ, ДАТ, рівнем загального холестерину, тригліцеридів, лпВщ, лПНЩ, коефіцієнтом атерогенності

\begin{tabular}{|c|c|c|c|c|c|c|c|c|c|}
\hline & IMT & ЖM & CAT & ДАТ & Хол. & Тригліцериди & лпВщ & лпнщ & $\begin{array}{c}\text { Коефіцієнт } \\
\text { атеро- } \\
\text { генності }\end{array}$ \\
\hline IMT & 1 & & & & & & & & \\
\hline ЖM & 0,78 & 1 & & & & & & & \\
\hline CAT & 0,51 & 0,45 & 1 & & & & & & \\
\hline ДАТ & 0,60 & 0,48 & 0,88 & 1 & & & & & \\
\hline Холестерин & $-0,05$ & $-0,14$ & 0,18 & 0,08 & 1 & & & & \\
\hline Тригліцериди & 0,17 & 0,18 & 0,54 & 0,51 & 0,25 & 1 & & & \\
\hline лпВЩ & $-0,54$ & $-0,36$ & $-0,43$ & $-0,41$ & 0,00039 & $-0,47$ & 1 & & \\
\hline лПнЩ & $-0,22$ & $-0,27$ & $-0,12$ & $-0,18$ & 0,82 & $-0,07$ & 0,02 & 1 & \\
\hline $\begin{array}{l}\text { Коефіцієнт } \\
\text { атерогенності }\end{array}$ & 0,06 & $-0,13$ & 0,23 & 0,15 & 0,56 & 0,47 & $-0,67$ & 0,58 & 1 \\
\hline
\end{tabular}

Примітка. В таблиці представлені числові значення R - коефіцієнта кореляції Пірсона. Рівень похибки р<0,05.

біоелектронної імпедансметрії зокрема на підвищення артеріального тиску та визначення його як маркера кардіометаболічного ризику, що, ймовірно, викликано зростанням рівня загального холестерину, дисліпідемією, активацією системного запалення, збільшенням продукції підшкірною жировою тканиною медіаторів запалення та подальшими змінами (ремоделюванням) судинної стінки. 3 огляду на те, що виявлено сильний прямий статистично значущий кореляційний зв'язок між відсотком ЖМ (див. табл. 3) та IMT, обводами талії, стегон, шиї та іншими антропометричними показниками, біоімпедансне зважування, як метод діагностики, можна вважати достовірним клінічним інструментом для виявлення кардіометаболічного ризику у пацієнтів з АГ та ожирінням або зайвою вагою.

Висновки. 1. Виявлені кореляційні зв'язки між показниками антропометрії, морфомертії та показниками лабораторних досліджень. Встановлено, що показники \% ЖМ, ІМТ, обводу талії, стегон, шиї, кистей, а також показники систолічого та діастолічного артеріального тиску в групі пацієнтів з АГ та ожирінням/зайвою вагою позитивно корелюють між собою з коефіцієнтом кореляції різного ступеня, що не залежить від віку. Зокрема, $\%$ ЖМ позитивно корелює з вагою тіла - $r=0,68$, $p=0,001$, з IMT $-r=0,78$ та окружністю талії $-r=0,73$, $p=0,001$, стегон $-r=0,82, p=0,001$, САТ $-r=0,45$ та ДАТ $-r=0,48(p<0,05)$. У групі здорових осіб вияв- лено сильну пряму кореляцію IMT з віком $\mathrm{r}=0,96$, $\mathrm{p}=0,03$. Отже, можемо припустити, що антропометричні й морфометричні показники мають більшу вагу, ніж віковий фактор, у осіб, які мають ожиріння на фоні АГ, а у групі без АГ та ожиріння основним фактором ризику $\epsilon$ вік.

2. Показники ЛПВЩ мають зворотний кореляційний зв'язок із САТ та IMT, зокрема, ЛПВЩ та IMT - r = -0,54, p=0,0008, ЛПВЩ і САТ - r=-0,43, $\mathrm{p}=0,04 . \%$ ЖМ також продемонстрував тенденцію до зв'язку з ЛПВЩ, але без статистичної достовірності. Виявлено пряму кореляцію рівня систолічного $(r=0,54, p=0,0087)$ та діастолічного АТ $(r=0,51$, $\mathrm{p}=0,01)$ з рівнем тригліцеридів, але не було виявлено суттєвих кореляцій із загальним рівнем холестерину та лпнщ.

3. Включення морфометричних вимірювань методом біоелектронної імпедансметрії (БІМ) разом із традиційними антропометричними вимірюваннями у повсякденну клінічну практику $\epsilon$ не тільки безпечним і неінвазивним, а й найбільш точним і достовірним методом, який можна рекомендувати як пріоритетний для діагностики ожиріння/ зайвої ваги та визначення ризику в пацієнтів із та без АГ на первинній ланці охорони здоров'я.

Перспективи подальших досліджень пов'язані з розробкою індивідуальних дієтичних рекомендацій та комплексів фізичної реабілітації для осіб з дисбалансом жирової складової тіла відповідно до даних морфо-та антропометрії.

\section{ЛІТЕРАТУРА}

1. Trends in adult body-mass index in 200 countries from 1975 to 2014: a pooled analysis of 1698 populationbased measurement studies with 19.2 million participants / NCD Risk Factor Collaboration (NCD-RisC) // Lancet. - 2016. - Vol. 387, No. 10026. - P. 1377-1396.
2. The global cardiovascular risk transition: associations of four metabolic risk factors with national income, urbanization, and Western diet in 1980 and 2008 / G. Danaei, G. M. Singh, C. J. Paciorek [et al.] // Circulation. 2013. - Vol. 127, No. 14. - P. 1493-1502, 1502e1-1502e8. 
Огляди літератури, оригінальні дослідження, погляд на проблему, випадок з практики, короткі повідомлення

3. Obesity and overweight [Electronic resource] / WHO. - URL : https://www.who.int/news-room/factsheets/detail/obesity-and-overweight . - Title from the screen.

4. Mandviwala T. Obesity and cardiovascular disease: a risk factor or a risk marker? / T. Mandviwala, U. Khalid, A. Deswal // Curr. Atheroscler. Rep. - 2016. - Vol. 18, No. 5. - Art. No 21.

5. A study on body mass index and its correlation with type 2 diabetes / S. C. Jain, R. P. Gupta, D. Gupta, M. K. Jain // Int. J. Res. Med. Sci. - 2014. - Vol. 2, No. 4. - P. 1638-1641.

6. Petrie J. R. Diabetes, hypertension, and cardiovascular disease: clinical insights and vascular mechanisms / J. R. Petrie, T. J. Guzik, R. M. Touyz // Can. J. Cardiol. 2018. - Vol. 34, No. 5. - P. 575-584.

7. Bhupathiraju S. N. Epidemiology of obesity and diabetes and their cardiovascular complications / S. N. Bhupathiraju, F. B. Hu // Circ. Res. - 2016. - Vol. 118, No. 11. P. 1723-1735.

8. Hoffer E. C. Correlation of whole-body impedance with total body water volume / E. C. Hoffer, C. K. Meador, D. C. Simpson // J. Appl. Physiol. - 1969. - Vol. 27, No. 4. P. 531-534.

9. Siri W. E. Body composition from fluid spaces and density: analysis of methods. 1961 / W. E. Siri // Nutrition. - 1993. - Vol. 9, No. 5. - P. 480-491.

10. Densitometric analysis of body composition: revision of some quantitative assumptions / J. Brozek, F. Grande, J. T. Anderson, A. Keys // Ann. N. Y. Acad. Sci. 1963. - Vol. 110. - P. 113-140.

11. Chula de Castro J. A. Body composition estimation in children and adolescents by bioelectrical impedance analysis: a systematic review / J. A. Chula de Castro, T. R. Lima, D. A. S. Silva // J. Bodyw. Mov. Ther. - 2018. Vol. 22, No. 1. - P. 134-146.

12. Гриньків М. Я. Спортивна морфологія (з основами вікової морфології) : навч. посіб. / М. Я. Гриньків, Л. С. Вовканич, Ф.В.Музика. - Львів : ЛДУФК, 2015. $300 \mathrm{c}$.

\section{REFERENCES}

1. NCD Risk Factor Collaboration. (2016). Trends in adult body-mass index in 200 countries from 1975 to 2014: a pooled analysis of 1698 population-based measurement studies with 192 million participants. The Lancet, 387 (10026), 1377-1396.

2. Danaei, G., Singh, G.M., Paciorek, C.J., Lin, J.K., Cowan, M.J., Finucane, M.M., ... \& Rao, M. (2013). The global cardiovascular risk transition: associations of four metabolic risk factors with national income, urbanization, and Western diet in 1980 and 2008. Circulation, 127 (14), 1493-1502.

3. World Health Organization. (2017). Adolescent obesity and related behaviours: trends and inequalities in the WHO European Region, 2002-2014. World Health Organization. Regional Office for Europe.

4. Mandviwala, T., Khalid, U., \& Deswal, A. (2016). Obesity and cardiovascular disease: a risk factor or a risk marker? Current Atherosclerosis Reports, 18 (5), 21.

5. Jain, S.C., Gupta, R.P., Gupta, D., \& Jain, M.K. (2014). A study on body mass index and its correlation with type 2
13. Association of all-cause mortality with overweight and obesity using standard body mass index categories: a systematic review and meta-analysis / K. M. Flegal, B. K. Kit, H. Orpana, B. I. Graubard // JAMA. - 2013. - Vol. 309, No. 1. - P. 71-82.

14. Body mass index, the most widely used but also widely criticized index: would a criterion standard measure of total body fat be a better predictor of cardiovascular disease mortality? / F. B. Ortega, X. Sui, C. J. Lavie, S. N. Blair // Mayo Clin. Proc. - 2016. - Vol. 91, No. 4. - P. 443-455.

15. Bioelectrical impedance analysis - part I: review of principles and methods / U. G. Kyle, I. Bosaeus, A. D. De Lorenzo [et al.] // Clin. Nutr. - 2004. - Vol. 23, No. 5. P. 1226-1243.

16. Comparison of body composition assessment by DXA and BIA according to the body mass index: A retrospective study on 3655 measures / N. Achamrah, G. Colange, J. Delay [et al.] // PLoS One. - 2018. - Vol. 13, No. 7. Art. No e0200465.

17. Вороненко Н. Ю. Комп'ютерна томографія, ультразвукове сканування та біоімпеданансометрія як методи дослідження абдомінальної жирової тканини у жінок з метаболічним синдромом / Н. Ю. Вороненко, І. М. Дикан, О. І. Мухомор // Здоровье женщины. 2013. - № 7. - С. 128-135.

18. Биоимпедансный анализ состава тела человека / Д. В. Николаев, А. В. Смирнов, И. Г. Бобринская, С. Г. Руднев. - М. : Наука, 2009. - 390 с.

19. Waist circumference and waist-hip ratio : report of a WHO Expert Consultation, Geneva, 8-11 December 2008. - Geneva : WHO, 2011. - 39 p.

20. Артеріальна гіпертензія. Оновлена та адаптована клінічна настанова, заснована на доказах (2012 рік) // Артериал. гипертензия. - 2012. - № 1. C. 96-152.

21. Ожиріння в практиці кардіолога та ендокринолога / О. М. Біловол, О. М. Ковальова, С. С. Попова, О. Б. Тверетінов. - Тернопіль : ТДМУ : Укрмедкнига, 2009. -618 c.

diabetes. International Journal of Research in Medical Sciences, 2 (4), 1638

6. Petrie, J.R., Guzik, T.J., \& Touyz, R.M. (2018). Diabetes, hypertension, and cardiovascular disease: clinical insights and vascular mechanisms. Canadian Journal of Cardiology, 34 (5), 575-584.

7. Bhupathiraju, S.N., \& Hu, F.B. (2016). Epidemiology of obesity and diabetes and their cardiovascular complications. Circulation Research, 118 (11), 1723-1735.

8. Hoffer, E.C., Meador, C.K., \& Simpson, D.C. (1969). Correlation of whole-body impedance with total body water volume. Journal of Applied Physiology, 27 (4), 531-534.

9. Siri, W.E. (1961). Body composition from fluid spaces and density: analysis of methods. Techniques for Measuring Body Composition, 61, 223-244.

10. Brozek, J., Grande, F., Anderson, J. T., \& Keys, A. (1963). Densitometric analysis of body composition: revision of some quantitative assumptions. Annals of the New York Academy of Sciences, 110 (1), 113-140. 
Огляди літератури, оригінальні дослідження, погляд на проблему, випадок з практики, короткі повідомлення

11. Castro de, J.A.C., de Lima, T.R., \& Silva, D.A.S. (2018). Body composition estimation in children and adolescents by bioelectrical impedance analysis: A systematic review. Journal of Bodywork and Movement Therapies, 22 (1), 134-146.

12. Hrynkiv, M., Vovkanych, L., \& Muzyka, F. (2015). Sportyvna morfolohiia (z osnovamy vikovoi morfolohii). [Sports morphology (with basics of age morphology)]. Lviv: LDUFK [in Ukrainian].

13. Flegal, K.M., Kit, B.K., Orpana, H., \& Graubard, B.I. (2013). Association of all-cause mortality with overweight and obesity using standard body mass index categories: a systematic review and meta-analysis. Jama, 309 (1), 71-82.

14. Ortega, F.B., Sui, X., Lavie, C.J., \& Blair, S.N. (2016). Body mass index, the most widely used but also widely criticized index: would a criterion standard measure of total body fat be a better predictor of cardiovascular disease mortality?. In Mayo Clinic Proceedings (91), 4, 443-455. Elsevier.

15. Kyle, U.G., Bosaeus, I., De Lorenzo, A.D., Deurenberg, P., Elia, M., Gómez, J.M., ... \& Scharfetter, H. (2004). Bioelectrical impedance analysis-part I: review of principles and methods. Clinical Nutrition, 23 (5), 1226-1243.

16. Achamrah, N., Colange, G., Delay, J., Rimbert, A., Folope, V., Petit, A., ... \& Coëffier, M. (2018). Comparison of body composition assessment by DXA and BIA according

to the body mass index: a retrospective study on 3655 measures. PloS One, 13 (7).

17. Voronenko, N.Yu., Dykan, I.M., \& Mukhomor, O.I. (2013). Kompiuterna tomohrafiia, ultrazvukove skanuvannia ta bioimpedansometriia yak metody doslidzhennia abdominalnoi zhyrovoi tkanyny u zhinok z metabolichnym syndromom [Computed tomography, ultrasound scanning and bioimpedancemetry as methods for the study of abdominal adipose tissue in women with metabolic syndrome]. Zdorovye zhenshchiny - Woman's Health (7), 128135 [in Ukrainian].

18. Nikolayev, D.V., Smirnov, A.V., Bobrinskaya, I.G., \& Rudnev, S.G. (2009). Bioimpedansnyy analiz sostava tela cheloveka [Bioimpedance analysis of human body]. Moscow: Nauka [in Russian].

19. World Health Organization. (2011). Waist circumference and waist-hip ratio: report of a WHO expert consultation, Geneva, 8-11 December 2008.

20. Svishchenko, Ye.P. (2012). Arterialna hipertenziia. Onovlena ta adaptovana klinichna nastanova, zasnovana na dokazakh [Hypertension. Updated and adapted evidencebased clinical setting]. Novosti meditsyny i farmatsii - Medicine and Pharmacy News, 422, 24-31 [in Ukrainian].

21. Bilovol, O.M., Kovalova, O.M., Popova, S.S., \& Tveretinov, O.B. (2009). Ozhyrinnia v praktytsi kardioloha ta endokrynoloha [Obesity in the practice of cardiologist and endocrinologist.] Ternopil: Ukrmedknyha [in Ukrainian].

\title{
МОРФОМЕТРИЧЕСКИЕ И АНТРОПОМЕТРИЧЕСКИЕ ОБСЛЕДОВАНИЯ ПРИ ВЕДЕНИИ ПАЦИЕНТОВ С АРТЕРИАЛЬНОЙ ГИПЕРТЕНЗИЕЙ И ОЖИРЕНИЕМ
}

\author{
๑Л. Ф. Матюха, Е. Ю. Гончарук
}

\author{
Национальная медицинская академия последипломного образования имени П. Л. Шупика
}

РЕЗЮМЕ. Статья посвящена результатам антропометрического и морфометрического исследования методом биоэлектрического импеданс-анализа пациентов с артериальной гипертензией и ожирением/лишним весом.

Цель - исследовать и проанализировать антропометрические и морфометрические показатели у пациентов с артериальной гипертанзией и ожирением/лишним весом и сравнить показатели морфометрии с антропометрическими и биохимическими показателями у пациентов исследуемых групп.

Материал и методы. Обследованы 64 пациента с артериальной гипертензией и ожирением и 21 здоровый

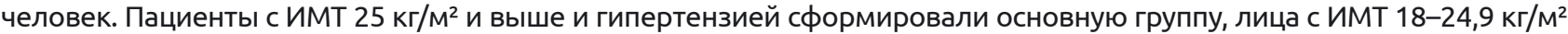
без гипертнзии вошли в контрольную группу. Все пациенты прошли клиническое, антропометрические, морфометрические и лабораторное обследования, которые включали измерение АД, определение роста, массы тела, окружности талии, шеи, кистей и бедер, определение уровня глюкозы натощак, общего холестерина, лПВП, лПнП, ЛПОНП, определение коэффициента атерогенности и процентной доли жира в организме, измеренного методом биоимпедансметрии (БИМ). БИМ проводили анализатором композиции тела OMRON Body Composition Monitor BF212 (Japan), 2012 Статистическую обработку данных проводили с помощью SPSS Statistics ver. 23.0.0.

Результаты. обнаружены корреляционные связи между антропометрическими, морфометрическими и лабораторными показателями, в частности, \% ЖМТ, ИМТ, САД и ДАД, а также ЛПВП, триглицеридами в основной группе, независимо от возраста, и корреляцию между ИМТ и возрастом в группе здоровых лиц.

Выводы. Процент ЖМ положительно коррелирует с массой тела - $r=0,68, p=0,001$, с ИМТ - $=0,78$ и окружностью талии - $r=0,73$ p=0,001, бедер - $r=0,82, p=0,001$, САД - $r=0,45$ и ДАД - $r=0,48$ ( $p<0,05)$. В группе здоровыХ лиц обнаружена сильная прямая корреляция ИМТ с возрастом - $r=0,96, p=0,03$, следовательно, можем предположить, что антропометрические, морфометрические показатели имеют больший вес, чем возрастной фактор, у лиц, имеющих ожирение на фоне АГ, а в группе без АГ и с ожирением основным фактором риска является возраст. Включение морфометрических измерений в повседневную клиническую практику является безопасным, неинвазивным, точным и достоверным методом диагностики ожирения/лишнего веса и определения риска.

КЛючЕВЫЕ СЛОВА: ожирение; артериальная гипертензия; биоимпедансметрия. 
Огляди літератури, оригінальні дослідження, погляд на проблему, випадок з практики, короткі повідомлення

\title{
MORPHOMETRIC AND ANTHROPOMETRIC EXAMINATION IN THE MANAGEMENT OF PATIENTS WITH ARTERIAL HYPERTENSION AND OBESITY
}

\author{
@L. F. Matyukha, O. Yu. Goncharuk \\ P. Shupyk National Medical Academy of Postgraduate Education, Kyiv
}

SUMMARY. The article is devoted to the results of anthropometric and morphometric examination by bioelectric impedance analysis of patients with hypertension and obesity/overweight.

The aim is to investigate and analyze anthropometric and morphometric indices in patients with hypertension and obesity/overweight and to compare morphometric indices with anthropometric and biochemical indices in patients in the study groups.

Material and Methods. 64 patients with hypertension and obesity and 21 healthy persons were examined. Patients with a BMl of $25 \mathrm{~kg} / \mathrm{m}^{2}$ and above and hypertension formed the main group; patients with a BMl of $18-24.9 \mathrm{~kg} / \mathrm{m}^{2}$ without hypertension were included in the control group. All patients underwent clinical, anthropometric, morphometric and laboratory examination, which included blood pressure, height, body weight, circumference of the waist, neck, hands and thighs, fasting glucose, total cholesterol, HDL, LDL, LDL atherogenicity and percentage of fat in the body as measured by bioimpedancemetry (BIM). BIM was performed by OMRON Body Composition Monitor BF212, (Japan), 2012. Statistical data processing was performed using SPSS Statistics ver. 23.0.0.

Results. Correlations were found between anthropometric, morphometric, and laboratory parameters, including \%FM, BMI and SBP and DBP, as well as HDL, triglycerides in the main group, regardless of age and correlation between $\mathrm{BMI}$ and age in the healthy group.

Conclusions. \%FM positively correlates with body weight $-r=0.68, p=0.001$, with $B M I r=0,78$ and waist circumference $r=0.73 p=0.001$, hips $r=0.82, p=0.001$, SBP $r=0.45$ and DBP $r=0.48$, at $p<0.05$. In the group of healthy individuals we revealed a strong direct correlation of BMI with age $r=0.96, p=0.03$, therefore, we can assume that anthropometric, morphometric indicators have more weight than the age factor in individuals who have obesity and hypertension, and in the group without hypertension and obesity, the main risk factor is age. Incorporating morphometric measurements into everyday clinical practice is a safe, non-invasive, accurate and reliable method of diagnosing obesity/overweight and determining risk.

KEY WORDS: obesity; hypertension; bioelectrical impedance analysis.

Отримано 12.02.2020 